\title{
ELITES URBANAS Y COMANDANTES DE FRONTERA: UNA INTERPRETACION DE LA REVOLUCION LIBERAL DE 1861 EN CORRIENTES
}

\author{
Pablo Buchbinder
}

\section{Poder y territorio en las décadas de 1830 y $1840^{1}$}

En noviembre de 1861, una revolución encabezada por los jefes de los departamentos de Mercedes y Curuzú Cuatiá provocó el derrocamiento del gobierno provincial correntino liderado por José María Rolón. Las localidades mencionadas eran departamentos de frontera y su incorporación a la jurisdicción provincial era relativamente reciente. Sin embargo, como se manifestó en el episodio revolucionario su capacidad para determinar los rumbos de la vida política local era ya decisiva. El propósito de este trabajo consiste en explorar algunas dimensiones de este proceso, sobre todo los vinculados con el ascenso político de grupos de poder radicados en un área de la frontera rioplatense y con la relación de dichos grupos con el gobierno asentado en la ciudad capital de la provincia que ejercía jurisdicción sobre dicho territorio. En este contexto, tratamos de analizar los factores que impulsaron la revolución y las consecuencias de ésta sobre la estructura institucional y política correntina. A partir de aquí procuramos sugerir una serie de vías interpretativas para analizar el modo en que la provincia se integró en el estado nacional y los orígenes de la inestabilidad política y decadencia económica que la caracterizaron durante toda la segunda mitad del siglo XIX. Es preciso recordar aquí que la revolución a la que nos referimos tuvo profundas raíces locales pero coincidió con toda una serie de movimientos similares en distintas provincias que permitieron el ascenso al poder de sectores liberales afectos al Gobernador de la Provincia de Buenos Aires, Bartolomé Mitre ,y opuestos al antiguo líder de la "Confederación Argentina", Justo José de Urquiza. Como en Corrientes, en la mayoría de las provincias argentinas episodios de estas características acaecidos poco tiempo después de la batalla de Pavón de septiembre de 1861, hicieron posible el inicio de la conformación de un estado nacional bajo el liderazgo de Buenos Aires. Hacia finales del siglo XIX ya varias de las figuras más relevantes de la vida política e intelectual correntina hacían un balance negativo de ese proceso de integración en el estado nacional ${ }^{2}$.

\footnotetext{
${ }^{1}$ La investigación que hizo posible la elaboración de este texto contó con financiamiento de la Agencia Nacional de Promoción Científica y Tecnológica y la Fundación Antorchas. Versiones preliminares se discutieron en el 51 Congreso de Americanistas celebrado en Santiago de Chile en julio de 2003 y en una reunión organizada en el Instituto de Historia de la Facultad de Humanidades de la Universidad Nacional del Nordeste en noviembre del mismo año. El autor agradece los comentarios efectuados por los participantes en dichas reuniones, en particular los vertidos por Enrique Schaller.

${ }^{2} \mathrm{Al}$ respecto véase Hernán Gómez, Reintegración de Misiones a la Provincia de Corrientes, en Hernán Félix Gómez, Páginas de Historia, Imprenta del Estado, Corrientes, 1928.
} 
A pesar de su condición de provincia litoraleña, Corrientes no logró participar de los beneficios de la incorporación al mercado internacional en una medida similar a la de otras provincias argentinas vecinas como Entre Ríos o Santa Fe. Sus élites políticas también fracasarían en el intento de incidir en las decisiones tomadas desde el gobierno nacional, lo que puede observarse, entre otros factores, en el escaso peso de los hombres de la provincia en los gabinetes nacionales. Creemos que a partir del análisis de los procesos que indagamos en este trabajo pueden inferirse algunas de las causas de ese fracaso.

Con la revolución arriba mencionada se expresó claramente un hecho resaltado por muchos de quienes se dedicaron al análisis de la historia correntina del siglo XIX: las dificultades de la ciudad de Corrientes para controlar la totalidad del territorio sobre el que ejercía teóricamente su jurisdicción. Corrientes había sido fundada a fines del siglo XVI sobre el río Paraná por parte de conquistadores que procuraban instalar un paso en la ruta fluvial entre Buenos Aires y Asunción y rápidamente fue expandiéndose hacia el sur. Como puede observarse a partir de los mapas, el territorio que ocuparía posteriormente la provincia se encuentra dividido por un río, el Corrientes, que la recorre desde el sudeste hacia el nordeste y que se prolonga posteriormente en los esteros del Iberá. Este río constituyó un límite díficilmente franqueable para los hombres de la élite urbana de la ciudad capital. La imposición de la jurisdicción de ésta sobre los territorios situados al otro lado del río Corrientes y que integrarían tiempo más tarde el sur y el este de la provincia fue relativamente tardía. En el este, en las proximidades del río Uruguay se instalaron desde el siglo XVII varias de las más importantes Misiones Jesuíticas. A la región del sur, donde se conformarían los partidos de Curuzú Cuatiá y Mercedes, las fuerzas de la ciudad llegaron a finales del siglo XVIII y principios del XIX. Por entonces, ocuparon prácticamente en su totalidad la región del llamado Pai Ubre ( el territorio correspondiente al futuro partido de Mercedes). En 1810, Manuel Belgrano fundó el pueblo de Curuzú Cuatiá y lo incorporó a la jurisdicción de la ciudad de Corrientes. Este pueblo sería, durante décadas, un punto de avanzada de la frontera correntina. Su dominio sería disputado por indígenas, grupos provenientes de las Misiones y fuerzas entrerrianas hasta entrado el siglo XIX. ${ }^{3}$

El reconocimiento del poder provincial sobre la región del este, más allá del río Miriñay en las cercanías del Uruguay fue todavía más tardío. Con la expulsión de los jesuitas se inició un proceso de decadencia y caída demográfica en toda la región. Este se agudizó con las guerras de la independencia ya que toda la zona fue escenario de las luchas en las que tomaron parte las fuerzas criollas, las provenientes de Buenos Aires y las del Paraguay que resistían a las primeras. Las desaveniencias entre los propios grupos revolucionarios también se desenvolvieron en esa parte del futuro territorio de la provincia. La influencia artiguista, por otro lado, se hizo sentir con fuerza hasta la derrota militar definitiva del caudillo oriental en 1820. Así, la jurisdicción sobre toda esta región fue disputada con Entre Ríos e incluso hubo proyectos para crear allí una entidad política independiente.

\footnotetext{
${ }^{3}$ Sobre la expansión de la ciudad de Corrientes durante el período colonial puede verse el texto de Ernesto Maeder, Historia económica de Corrientes durante el periodo virreinal, Academia Nacional de la Historia, Buenos Aires, 1981.
} 
Finalmente, en 1830, un acuerdo con los líderes del pueblo de La Cruz, una antigua reducción jesuítica, hizo posible el reconocimiento del dominio de la ciudad sobre toda la zona ${ }^{4}$. Por entonces, el gobierno provincial liderado por Pedro Ferré inició un activo proceso de colonización en el sur y en el este. Procuró fundar distintos pueblos que garantizasen el ejercicio de la jurisdicción de la capital de la provincia y facilitasen el proceso de repoblación de esas áreas de frontera. ${ }^{5}$

Sobre todos estos territorios se impuso la organización administrativa propia del estado provincial. Este estaba dividido en departamentos al frente de los cuales se encontraba un Comandante Militar, asistido, generalmente, por un juez de paz. El comandante reunía amplias atribuciones siendo responsable, no sólo del reclutamiento de la tropa, sino también de las funciones policiales y hasta de la higiene y las obras públicas. En épocas de guerra tenían también facultades discrecionales para aplicar contribuciones forzosas. Por otra parte, el jefe departamental aseguraba el poder del estado en áreas de frontera y oficiaba como intermediario entre la sociedad local y las autoridades asentadas en la ciudad capital. En las áreas de frontera o de reciente colonización podía manejarse además con un alto grado de discrecionalidad a partir de la acumulación de cuotas considerables de poder en lo fiscal, lo judicial y lo militar. De todos modos, los departamentos del sur y del este de la provincia adquirieron una serie de particularidades. En primer lugar, su carácter de localidades de frontera se correspondía con un intenso grado de militarización. Por otro lado, se caracterizaban por una extremadamente baja densidad demográfica, por el predominio de la gran propiedad y de un sistema económico orientado casi exclusivamente hacia la producción ganadera ${ }^{6}$.

Es importante tener en cuenta también aquí que los jefes departamentales en tanto máximas autoridades municipales tenían la potestad de ejercer el control de las elecciones a partir de las cuales se designaba a los miembros de la legislatura local ya que el Reglamento Provisorio Constitucional de 1824 había establecido que el Juez y el comandante de cada partido presidiesen y organizasen los actos electorales. ${ }^{7}$ Ya las autoridades nacidas de la revolución de diciembre de 1821, que, por otra parte, había garantizado la autonomía provincial, habían dispuesto que los comandantes militares de los departamentos se ocupasen de la elección de los diputados por parte de los miembros del vecindario encareciéndoles que se ajustasen a la "libre y espontánea" voluntad de los ciudadanos. ${ }^{8}$

\footnotetext{
${ }^{4}$ Sobre la desintegración del territorio misionero y su incorporación a la jurisdicción correntina véase Edgar Poenitz y Alfredo Poenitz, Misiones, Provincia Guaranítica, Editorial Universitaria, Posadas, 1998.

${ }^{5}$ Para entender este proceso es útil la consulta de las Memorias de Pedro Ferré, Memoria del Brigadier General Don Pedro Ferré, Buenos Aires, Imprenta y Casa editora Coni, Buenos Aires, 1921.

${ }^{6}$ Véase al respecto los comentarios de Martín de Moussy en su Description Geographique et Statistique de la Confederation Argentine, París, Tomo III, 1864, pp 121 y siguientes. De Moussy señalaba que, si bien la industria pastoril era la principal ocupación de los habitantes de la provincia de Corrientes era prácticamente la única en los departamentos situados al sur del río del mismo nombre.

${ }^{7}$ Veáse Reglamento Provisorio Constitucional de la Provincia de Corrientes, Septiembre 22 de 1824, Sección Tercera. En Recopilación de Constituciones de la Provincia de Corrientes, Edición Oficial, Imprenta del Estado, Corrientes, 1921.

${ }^{8}$ Hernán Gómez, Provincialización de Corrientes, Corrientes, Imprenta del Estado, 1921.
} 
El comandante departamental pasó así a cumplir una función esencial en el sistema político ya que como se sabe, las elecciones constituían, en el Río de la Plata como en otras partes de Sudamérica, el principal mecanismo de legitimación de las autoridades.

Por otro lado, es preciso señalar aquí que, en muchos casos, el gobernador conservó un margen de poder suficiente para llevar a cabo la designación de los Jefes de Departamento con cierta independencia de las redes de influencia local. Pero, en la medida en que en las distintas regiones de la provincia y particularmente en las de reciente colonización del sur y del este se fueron consolidando nuevos núcleos de poder e intereses, la cuota de poder que conservaban los funcionarios asentados en la ciudad capital tendió a disminuir considerablemente. El poder militar y el poder politico efectivo quedaron así en manos de los jefes departamentales quienes, a menudo, sólo en teoría, seguían siendo funcionarios auxiliares del gobernador.

El proceso de expansión de la provincia y de incorporación de nuevos territorios fue alterando entonces muchas de las variables que habían caracterizado a su sistema político, económico e institucional. Corrientes presentaba una serie de particularidades que la habían distinguido en las primeras décadas del período postindependentista del resto de las provincias del litoral rioplatense. Durante las décadas de 1820 y principios de la de 1830 el gobierno y el estado provincial estuvieron ferréamente controlados por una élite política de letrados, mercaderes y artesanos dedicados al comercio de la yerba, la explotación y procesamiento de la madera o al negocio de las curtiembres y asentados en la ciudad capital. Esta élite organizó un sistema político regido por el respeto estricto a reglas y procedimientos constitucionales en el que varios gobernantes se sucedieron entre 1821 y $1838 .{ }^{9}$ Además el gobierno provincial pudo organizar, durante estos años, un eficiente sistema fiscal basado en los aranceles a la importación lo que le permitió no implementar de modo sistemático contribuciones extraordinarias a los sectores propietarios como en otras provincias. Esto, a la vez, contribuyó favorablemente a la estabilidad política e institucional correntina. Pero hacia finales de la década de 1830, cuando Corrientes había consolidado su proceso de expansión territorial distintas circunstancias comenzaron a modificar este estado de situación. La provincia se involucró entonces de manera activa en los emprendimientos armados contra el gobernador de la Provincia de Buenos Aires, Juan Manuel de Rosas cuestionando así la hegemonía de éste en el conjunto del espacio rioplatense. Las revueltas alteraron considerablemente los equilibrios presupuestarios de la provincia y se incrementó entonces, en forma acelerada, el déficit. El mismo crecimiento económico y demográfico de las regiones de frontera posibilitó también el aumento del poder de sectores militares, cuya hegemonía tenía una base esencialmente rural y que tenían una orientación mucho más decidida hacia la producción ganadera. Asi, los rasgos que acabamos de señalar y que habían hecho de la experiencia política correntina un fenómeno particular en el contexto rioplatense comenzaban a esfumarse a finales de la década de 1830 .

\footnotetext{
${ }^{9}$ Sobre el sistema político y la estructura institucional durante este período véase José Carlos Chiaramonte, Mercaderes del Litoral, FCE, Buenos Aires, 1991.
} 
Puede observarse entonces como en el sur, sobre todo en el departamento de Curuzú Cuatiá y en cierta medida también en el este provincial surgió, al amparo de las guerras y los enfrentamientos que sacudieron al litoral rioplatense un foco de poder con un grado de autonomía relevante. Allí la jurisdicción provincial se ejerció tardíamente sin llegar a asentarse por completo. Las variables determinadas por la configuración espacial de la provincia cumplieron aquí un papel fundamental. El río Corrientes constituía, por entonces, un límite difícilmente franqueable. Todavía en 1872, se señalaba en un informe presentado al Ministerio del Interior, el río separaba a los entonces departamentos mas ricos de la provincia (Mercedes y Curuzú Cuatiá) de las costas del Paraná. Sus crecidas, que no se producían en “...épocas fijas del año..." provocaban la inundación de los campos adyacentes en una extensión de entre una y tres leguas y media, imposibilitando toda comunicación entre su dos orillas, a veces por lapsos muy prolongados ${ }^{10}$. En consecuencia, aunque el puerto correntino de Goya era geográficamente más próximo que el entrerriano de Concordia las dificultades para atravesar el río Corrientes hacían que, para comerciar, los pobladores y hacendados de la zona sur correntina acudiesen con preferencia a este último $^{11}$. El otro factor que incidió decisivamente en esta reorientación del comercio fueron los bloqueos permanentes sobre el Paraná -principal vía fluvial utilizada hasta entonces por el comercio litoral- llevados a cabo durante el período en que Juan Manuel de Rosas gobernó la provincia de Buenos Aires. Esto afectó tanto al comercio como a la expansión territorial de las regiones del Paraná fortaleciendo a las próximas al río Uruguay. ${ }^{12}$

Sin embargo, la autonomía que adquirió la región allende el río Corrientes no puede entenderse únicamente en función de factores geográficos. El proceso de intensa militarización que tuvo lugar en dicha zona cumplió un papel central. Como ya señalamos, Corrientes mantuvo un notable grado de estabilidad política hasta 1839. A partir de entonces, el fuerte involucramiento del estado local en las guerras civiles y en las rebeliones contra Rosas alteró en forma decisiva el equilibrio político local. La provincia fue sede de varias de las revueltas más intensas contra aquel y esto forzó aceleradamente un proceso de militarización sobre todo en el sur de la provincia. Allí se asentaron los principales cuerpos militares correntinos destinados a luchar contra las fuerzas entrerrianas, que respaldaban por ese entonces al gobernador de la Provincia de Buenos Aires.

Es preciso, en este contexto, prestar atención a la naturaleza peculiar de los cuerpos milicianos organizados en el sur correntino. Varios trabajos publicados en los últimos años

\footnotetext{
${ }^{10}$ De Knut Linmark a S. E. El señor Ministro del Interior Dr. Dalmacio Vélez Sarfield, Enero 31 de 1872, en Memoria del Ministerio del Interior presentada al Congreso Nacional en 1872, Buenos Aires, 1872, pp 3549.

${ }^{11}$ Se señala en el Censo Nacional de 1869, en el apartado dedicado al partido Mercedes o Pay Ubre: El verdadero mercado de este punto central de Corrientes es la Concordia en Entre Ríos, y es á esta donde se conducen por tropas de carretas, grandes cargas de cuero, cerda, grasa y sebo en retorno de las mercaderías que de allí se toman para consumo de esta comarca. En Primer Censo de la República Argentina, Buenos Aires, Imprenta del Porvenir, 1872, pp 185.

${ }^{12} \mathrm{Al}$ respecto puede verse el trabajo de Enrique Schaller, La distribución de la tierra y el poblamiento de la provincia de Corrientes, Cuadernos de Geohistoria Regional N 31, Instituto de Investigaciones Geohistóricas, Resistencia, 1995.
} 
han abordado la cuestión relativa a la organización de la llamada Guardia Nacional y de las organizaciones armadas de distinto carácter que surgieron en el contexto del proceso de intensa militarización que caracterizó a la política latinoamericana de la primera mitad del siglo XIX. Estos trabajos han puesto énfasis en diferentes variables: en la existencia de concesiones materiales concretas a la tropa, en la posibilidad de recibir una paga mensual, como en la oportunidad de hacerse con los bienes del enemigo derrotado o de alimentarse con carne en forma regular ${ }^{13}$. El carisma de los jefes militares y la posibilidad de lograr un claro ascendiente sobre los soldados en función de este factor constituye, sin duda, en este contexto, otro elemento central.

Del mismo modo se ha insistido en la relación entre el servicio en la milicia local, transformada a partir de la década de 1850 en muchos casos en Guardia Nacional, y el ejercicio de la ciudadanía. En función de este concepto se articulaba estrechamente la participación en la vida pública y la defensa del orden interno ${ }^{14}$. A la vez era posible compatibilizar la actividad militar con las tareas productivas. Sin embargo, creemos que es preciso tener presente que las organizaciones milicianas podían asumir diferentes características en los distintos espacios provinciales. Las pautas de organización miliciana en la frontera sur correntina no responden a muchos de los rasgos habituales de las fuerzas militares del litoral rioplatense. En este sentido, la comparación de la estructura miliciana del sur correntino con la organización vigente en la vecina provincia de Entre Ríos puede aportar perspectivas útiles para comprender mejor su naturaleza y características.

Julio Victorica, en su Urquiza y Mitre, al recordar las características de la organización militar de Entre Ríos señalaba como uno de sus rasgos esenciales el estar compuesta por "ciudadanos armados", casi todos propietarios. ${ }^{15}$ La militarización entrerriana tal como se describe aquí y en otros trabajos, era sumamente ordenada, organizada a través de la estructura departamental y de los distritos de reclutamiento. Estaba fuertemente controlada por el estado provincial que había impedido, por ejemplo, que los milicianos acudiesen a la guerra con sus mujeres, había sistematizado la provisión y el abasto del alimento y la carne, y retribuía los servicios de jefes y oficiales a través de la concesión de "...suertes de estancias..." que, de todos modos, no pasaban a propiedad de éstos sino que permanecían como parte del patrimonio estatal. El estado provincial conservaba una notable capacidad para perseguir y castigar a los desertores o evitar, por ejemplo que éstos gastasen largos período de tiempo en las pulperías de campaña ${ }^{16}$.

${ }^{13}$ Un análisis de las estrategias y motivaciones vinculadas a la participación en la milicia para el caso de la provincia de la Rioja puede verse en Ariel de la Fuente, Children of Facundo: Caudillo and Gaucho Insurgency during the Argentine State-Formation Process (La Rioja 1853-1870), Duke University Press, Durham and London, 2000,

${ }^{14}$ Puede verse al respecto varios de los artículos incluidos en el volumen compilado por Hilda Sábato y Alberto Lettieri, La vida política en la Argentina del siglo XIX, Fondo de Cultura Económico, Buenos Aires, 2003.

15 Julio Victorica,Urquiza y Mitre, Hyspamérica, Buenos Aires, 1986, pp 12. La primera edición data de 1905. Un extenso y detallado análisis de la militarización entrerriana puede verse en Roberto Schmit "¿Gauchos de muchos rostros?. Guerra, Comercio y Producción rural en el Río de la Plata durante la primera mitad del siglo XIX", Ponencia presentada al XIII International Economic History Congress, Buenos Aires, Julio de 2002.

16 José María Sarobe, Urquiza, Buenos Aires, Guillermo Kraft, Ltda, 1941, Tomo I, pp 345. 
La militarización en el sur de Corrientes se diferenciaba sustancialmente de este modelo, descripto con cierta admiración por Sarmiento en sus observaciones sobre la organización del Ejército Grande ${ }^{17}$. En principio aparenta ser mucho más dependiente de las redes del poder político local y departamental y mucho menos de las autoridades provinciales. Las bases del poder caudillístico en el sur provincial se encontraban también en la propia habilidad del jefe departamental para convertirse en intermediario entre las autoridades asentadas en la capital de la provincia y la población de su propia localidad, en su rol como representante del poder público, en su capacidad, en este contexto, para asignar o eximir de deberes militares y fiscales e incluso en la posibilidad de utilizar los recursos de sus propiedades para sostener a la tropa aliada o sobornar a la enemiga. Sus jefes conservaron cuotas de autonomía, con respecto al estado provincial, mucho más grandes que sus símiles de Entre Ríos. Los testimonios de la década de 1840 mostraban como el estado correntino delegaba cada vez atribuciones más amplias en éstos. Tanto el reclutamiento como el abasto permanecían bajo el control de los mismos "hasendados" locales y a menudo los funcionarios del estado no conseguían que los "....vecinos." proporcionasen el abasto a la tropa con regularidad. Otra variable fundamental se vinculaba aquí con la dilatada extensión del territorio y su ya mencionada bajísima densidad de población. El peso númerico de las milicias era reducido y, en muchos casos, parecen estar compuestas por individuos que no tenían inserción en el aparato productivo de la región (Ver cuadro anexo).

Pero la militarización en Corrientes además de constituir un fenómeno extremadamente dependiente de las redes de poder departamental era también mucho más anárquica y desordenada lo que le otorgaba un tinte muy particular. Posiblemente el testimonio más claro al respecto sea el brindado por el general José María Paz en sus Memorias Póstumas. Como se sabe, Paz, un antiguo general de los tiempos de la independencia fue también un protagonista central de las luchas civiles de la primera mitad del siglo XIX. Lideró en diversas oportunidades a las fuerzas antirrosistas del interior argentino y a principios de la década de 1840 fue convocado por los hermanos Madariaga, entonces al mando de la provincia, para organizar sus milicias. Los Madariaga eran por entonces ya grandes propietarios y figuras influyentes en las localidades de Mercedes y Curuzú Cuatiá. Se habían desempeñado allí precisamente como comandantes departamentales, conservando entonces relaciones, poder e influencias. Su fuerza se asentaba, como señalaría Paz en el "gauchaje" donde la insubordinación, era, además, notaba el viejo general, una práctica permanente. En sus Memorias, teñidas sin duda por la visión de un entrenado militar de carrera, Paz denunciaba asombrado el alto grado de indisciplina y desorden que signaban a las fuerzas que comandaban los Madariaga. Esa indisciplina e insubordinación eran de tal magnitud que hacían que estas fuerzas no necesitasen de “...enemigos ni batalla para deshacerse..."18

${ }^{17}$ D.F. Sarmiento, Campaña en el Ejército Grande, Fondo de Cultura Económico, México, 1958, pp 130 y siguientes.

${ }^{18}$ Memorias Póstumas del General José María Paz, Tomo III, Buenos Aires, Talleres Gráficos de Luis Bernard, 1946,pp 236. 
Esta indisciplina y desorden tenía consecuencias de distinto tipo pero afectaba siempre de manera muy negativa la vida de las poblaciones civiles. La forma en la que los milicianos se apropiaban de los rodeos de ganado ajenos era una de esas maneras. Estas tropas habían hecho desaparecer estancias enteras, afirmaba Paz. Por otro lado, el antiguo guerrero de los tiempos de la independencia se asombraba de la escasez de medios y armamentos que aquejaba a esas mismas fuerzas. El carácter rudimentario y primitivo de su organización se reflejaba también en el estado de su armamento. Paz, atónito, afirmaba que los Madariaga utilizaban las añejas tácticas propias de los "caudillos" y que predicaban entre los gauchos el odio contra la parte "decente e ilustrada" de las poblaciones.

El ascenso social, la posibilidad de convertirse en gran propietario de tierras y ganado estaban estrechamente relacionados con el servicio en la milicia. Así coincidían estrechamente en las regiones del sur provincial la propiedad de la tierra, la jefatura efectiva de la milicia y la del Departamento. Por otra parte era posible que personas provenientes de sectores populares, como era habitual en zonas de frontera llegasen a ocupar posiciones institucionales prominentes. Era el caso de Nicanor Cáceres quien se convertiría en el caudillo hegemónico en la región desde 1840, prácticamente hasta finales de la década de 1860. Desde muy joven se había incorporado a la milicia participando a las órdenes de los ejércitos antirrosistas de Lavalle, de Paz y luego de Madariaga. Después de la derrota correntina en Vences pasó al servicio de Urquiza convirtiéndose al mismo tiempo en su agente político e incluso luego en su socio comercial. Así se transformó en un líder y jefe miliciano, a la vez de estanciero -en la década de 1860 era ya dueño de cuarenta mil hectáreas, sólo en Curuzú Cuatiá- y propietario de grandes rodeos de ganado. A finales de la década de 1840 llegó a ocupar el puesto de comandante general de armas de la Provincia. Cáceres era, se podría señalar, un típico caudillo carismático con competencia y capacidad para entrenar y disciplinar a soldados y oficiales. Su ascenso al primer plano de la política provincial revelaba el dinamismo y la movilidad que signaban a la sociedad y a la política de toda aquella región.

Paz señala como, en más de una ocasión, Joaquín Madariaga le había advertido el escaso valor de los hombres que el mismo comandaba. Estos sentían hacia la figura de Cáceres un respeto cuasi reverencial y entonces, con su ayuda, los Madariaga conseguían mantener sometida a la tropa "...esos hombres valen muy poco. Con sólo hacer venir a Nicanor Cáceres están metidos en un zapato”. El historiador correntino Florencio Mantilla destacó, en uno de sus primeros escritos como resultó imposible a los hermanos Madariaga mantener, en este contexto, subordinado a Cáceres ${ }^{19}$. Este último hacía permanentes observaciones a las órdenes de sus superiores. Por eso no era sorprendente, desde la perspectiva del historiador, que poco antes de Vences se hubiese declarado independiente de toda autoridad arrastrando con él a los jefes de los departamentos del sur. Esto le había permitido, a la vez, a Urquiza, hacerse con las mejores fuerzas de la caballería correntina.

${ }^{19}$ Manuel Florencio Mantilla, Estudios biográficos sobre patriotas correntinos, Amerindia Ediciones, Corrientes, 2001. La primera edición data de 1884. Sobre Cáceres puede verse Apuntes biográficos del General de la Nación Nicanor Cáceres por Severo Ortiz, Buenos Aires, Imprenta Buenos Aires, 1867. 
Diversos episodios muestran como era posible para los líderes de la región del sur conservar su independencia del poder político provincial asentado en la ciudad de Corrientes. Caceres protagonizó varias revueltas contra aquel en la década de 1850 que solo la misma intervención de Urquiza, entonces presidente de la Nacion, lograron neutralizar. El caudillo de Curuzú Cuatiá consiguió alterar el orden local utilizando milicias relativamente reducidas, no más de doscientos hombres, a muchos de los cuales el mismo mantenía en su estancia. Como ya señalamos, en el contexto de partidos muy extensos caracterizados por una extremadamente baja densidad demografica este tipo de organización miliciana podía desequilibrar las situaciones politicas con relativa facilidad. Esta estructura había crecido justamente durante los años cuarenta, las décadas de lucha militar más intensa en las que vio involucrada la provincia. Las fuerzas de Madariaga, que lideraron gran parte de la lucha antirrosista durante aquellos años, se sostenían, como señalaría Paz en el "gauchaje". Los hombres de estas milicias no conocían, señalaba Paz, la "parte moral de la disciplina" ni los procedimientos que regían el servicio de campaña.

Este proceso de autonomización de las estructuras militares del sudeste provincial se acentuó con los años. Como ya destacamos, Cáceres abandonó a los Madariaga y se pasó al bando urquicista poco antes de Vences, pero la estructura militar en aquella región no se modificó en sus características esenciales. Al comenzar la década de 1850 coexistía en Corrientes un poder político formal y legal, asentado en la ciudad con un fuerte núcleo de poder basado en un conjunto de caudillos, muchos de ellos jefes departamentales en el sur provincial. La élite de esta última región era más rústica y tenía un perfil más claramente militar que la del noreste de la provincia. Por otro lado, ya comenzaba a establecer lazos estrechos con algunos miembros relevantes de ésta que, durante las décadas de $1840 \mathrm{y}$ 1850 habían ido adquiriendo tierras en esa región en el marco de un proceso creciente de orientación hacia la actividad ganadera. Familias de grandes comerciantes asentados en la ciudad de Corrientes como los Lagraña, los Billinghurst o los Gelabert se fueron convirtiendo en propietarios de tierras de la zona sur de la provincia, sobre todo durante la década de 1850. Por ese entonces, sólo la ferréa dominación que el gobernador de la provincia de Entre Ríos ejercía sobre toda la región mantenía el equilibrio político del estado local correntino.

\section{El gobierno de Pujol: la década de 1850 y los intentos de reforma de la estructura departamental correntina.}

Durante la década de 1850 se verificó un intento de revertir las consecuencias del intenso proceso de militarización que había experimentado la provincia desde finales de la década de 1830. En cierta medida, estos intentos pueden leerse también como un ensayo por restaurar las características del orden político vigente en Corrientes antes de 1839 A mediados de 1852 había sido designado gobernador de la Provincia, Juan Pujol. ${ }^{20}$ Este,

\footnotetext{
${ }^{20}$ Sobre Pujol puede verse Hernán Gómez, Vida pública del Dr Juan Pujol, Buenos Aires, J. Lajouane, 1920. Sobre su acción de gobierno pueden consultarse también los trabajos de Ernesto Quesada, Pujol y la época de la Confederación, Buenos Aires, Imprenta Tragant, 1917. Una visión más reciente de este período puede leerse también en María Gabriela Quiñónez, La política en la época de Juan Pujol en Nordeste, Segunda Epoca, N 10, Resistencia, 1999, pp 44-78.
} 
nacido en noviembre de 1817 en Saladas, un partido cercano a la capital de la provincia, no era un personaje nuevo en la política correntina. Su trayectoria era la propia de un letrado de los tiempos coloniales y primera etapa de la independencia. Había estudiado en Córdoba donde recibió las borlas doctorales en Diciembre de 1838. Luego de desempeñarse como profesor de Latín y Filosofía en Buenos Aires, habia regresado a Corrientes donde una legislatura provincial en ese entonces antirrosista lo designó su prosecretario.

El gobernador Joaquín Madariaga lo nombró posteriormente Secretario de Guerra y Relaciones Exteriores. Durante los primeros años de la decada de 1840 Pujol demostró una particular preocupación por la organización administrativa, institucional y burocrática de la provincia. Procuró avanzar en las primeras versiones de un presupuesto para el estado y se esforzó por introducir nuevos criterios de organización burocrática estableciendo diferenciaciones en las atribuciones de los distintos ministerios y secretarías del gobierno provincial. En 1844 abandonó la actividad pública y se retiró a su establecimiento de campo en Saladas. Aparentemente, a finales de esa década Urquiza lo contactó en su estancia e incidió decisivamente para que retornase a la actividad pública. Pujol podía suministrar a la élite sus conocimientos en materia jurídica y administrativa y su extensa experiencia política. Además había participado activamente en las negociaciones que llevaron a la sanción de la Constitución de 1853. Esta circunstancia le proporcionaba un conjunto variado de contactos a nivel suprarregional, esenciales, en un período de construcción de una entidad política nacional.

Pujol trató de llevar a cabo un profundo proceso de transformación de la estructura institucional y de poder de la provincia. Este intento apuntaba esencialmente a limitar el poder creciente de los comandantes departamentales y procuraba entonces desmilitarizar gradualmente la organización administrativa provincial. En la perspectiva de Pujol la militarización de los departamentos impedía la constitución de una verdadera opinion pública que debía expresarse a tráves del voto popular y que sostendría, a la vez, un auténtico gobierno de instituciones. Para hacer entonces posible la construcción de "un gobierno de opinión" y asegurar el ejercicio de las libertades civiles y politicas era necesario limitar la influencia decisiva que los comandantes departamentales ejercían en las distintas localidades. Según el historiador correntino Hernán Gómez, Pujol advertía la imposibilidad de asentar un verdadero gobierno de "instituciones" en el marco del sistema de dominación ejercido por los comandantes departamentales. Precisamente era en el acto electoral donde la dominación del departamento por el despotismo militar se hacía evidente con mayor claridad. Como ya señalamos, el Reglamento Provisorio Constitucional, entonces vigente otorgaba a los Comandantes de Departamento el control de las Asambleas Electorales por las cuales se elegía a los diputados provinciales. Pero, desde la perspectiva de Pujol, el predominio de los jefes departamentales armados había anulado esa expresión fundamental de la vida cívica de los correntinos. En octubre de 1853, luego de realizadas una de las primeras elecciones en la provincia bajo su gobierno, Pujol enviaba una nota a los Presidentes de la Mesa Electoral manifestando su preocupación por la legitimidad de las nuevas autoridades. Sobre 18 mil almas habilitadas para votar sólo lo habían hecho 123 personas. Era este tipo 
de situaciones, señalaba el gobernador, las que había que evitar. ${ }^{21}$ Los testimonios de Pujol mostraban así como la ausencia de votantes generaba un evidente problema de legitimidad política a la vez que dejaba peligrosamente abierto el espacio para que el conflicto interno de las élites locales se resolviese unicamente a través de las armas. A través de las elecciones pretendía entonces Pujol crear una nueva estructura y nuevos actores políticos. Como podía evidenciarse a partir de sus discursos y escritos pensaba además a los votantes como personas individuales dotadas de plena autonomía para emitir su opinión.

Sin embargo, éste no era el único factor en el que se hacía evidente el predominio de los jefes de departamento sobre las estructuras políticas locales. Otra cuestión y seguramente no la menos importante se vinculaba con la forma en que éstos se apropiaban sistemáticamente de los recursos públicos como se puede advertir a partir de las quejas de Víctor Silvero, entonces principal responsable de la oficina de rentas local que denunciaba, indignado, las exacciones de los Comandantes Departamentales a las Receptorías encargadas, en el ámbito municipal, de la recaudación de impuestos y cánones enfiteuticos ${ }^{22}$. De este modo, el predominio de los jefes departamentales se hacía sentir sobre el funcionamiento global del sistema fiscal de la provincia. Es preciso recordar aquí que luego de la nacionalización de los ingresos aduaneros, Corrientes como otras provincias rioplatenses debió organizar su sistema fiscal a partir de nuevos tributos como la contribución directa. El sistema de percepción de ingresos provenientes de la propiedad de la tierra o de los bienes muebles estaba también fuertemente descentralizado quedando, en consecuencia, a merced de comisiones nombradas en los departamentos a cargo, entre otras cosas de la percepción de los cánones enfiteuticos, de los tributos provenientes de la contribución directa $\mathrm{y}$, en algunos casos, responsables también de la formación de los catastros. Las consecuencias negativas de esta organización para el fisco provincial no pasaban despercibidas para el mismo gobernador que señaló las graves consecuencias derivadas de esta estructura en varios de sus discursos. Estrechamente vinculado a la cuestión de la organización departamental estaba también el tema del régimen de propiedad de la tierra, asunto que preocupaba a las élites gobernantes durante la década de 1850 en Corrientes ya que ocupaba un lugar vital en sus proyectos de transformación de la sociedad provincial. Sin duda se trata de un problema muy complejo que debe ser analizado en función de distintas perspectivas. Es preciso recordar aquí que las formas de transferencia de la tierra al sector privado eran variadas e incluían la enfiteusis, la venta o la donación, básicamente por servicios administrativos y militares brindados al estado local. Hacia 1830 los gobiernos provinciales habían decidido privilegiar fundamentalmente la enfiteusis. Sin embargo, los problemas financieros del estado local forzaron a los gobernantes a reintroducir la venta a partir de los últimos años de esa

\footnotetext{
${ }^{21}$ Nota del Gobernador acusando recibo a la contestación de los Presidentes de la Mesa electoral e insistiendo en el mismo asunto en, Corrientes en la organización nacional, Buenos Aires, 1911, Tomo III, pp 279.

${ }^{22}$ Carta del administrador de Aduanas de la Provincia don Victor Silvero, Restauración, 16/8/1853, en Corrientes en la Organización Nacional, ob cit, Tomo III, pp 206 y ss. Sostenía entonces Silvero: "Las extracciones que se hagan de los fondos públicos, deben ser a impulso y mediante disposiciones expresas y acompañadas de la autorización competente que las justifique" En este contexto insistía también en la necesidad de evitar el manejo "siniestro" que de esos recursos pudiesen hacer tanto las autoridades civiles como las militares.
} 
misma década para resolver los problemas derivados del creciente déficit local ${ }^{23}$. Durante la década de 1840 y principios de la de 1850 tuvo lugar un acelerado proceso de apropiación de tierras fundamentalmente en las áreas de frontera.Los hombres de la élite gobernante en Corrientes durante la década de 1850 trataron de controlar ese proceso de privatización acelerada por varias razones. En este sentido es preciso recordar que la propiedad de la tierra involucraba, de algún modo también, el control sobre las poblaciones en ella asentadas. En segundo término era fundamental regular dicho proceso para que efectivamente respondiese a las crecientes necesidades del fisco, es decir, se trataba de que quienes se apropiasen de la tierra pagasen efectivamente por ella. Por último en los proyectos de desarrollo que Pujol y sus colaboradores pensaron para el futuro correntino el asentamiento de colonias de inmigrantes en parcelas pequeñas y medianas dedicados al cultivo de la tierra tenía una relevancia fundamental. Para cumplir con este objetivo era esencial mantener bajo control la transferencia a manos privadas.

Finalmente, la desmililitarización de la organización departamental, desde la perspectiva de Pujol y de sus colaboradores debía culminar con la creación de un auténtico sistema municipal y con una verdadera revitalización de los núcleos urbanos de la provincia. Aqui, entendían, iba a residir el principal sostén del gobierno provincial. Así, los hombres de la elite gobernante correntina aspiraban a reemplazar al poder militar "autónomo" y al "espiritu de caudillaje", por una autoridad "racional y humana" reproduciendo y extendiendo las redes de sociabilidad urbana. Las municipalidades eran concebidas como organizaciones democráticas cuyos miembros directivos iban a ser designados por el voto directo y a través de la participación popular. Además, estos debían ser empleados con renta y responsables por sus actos. La participación popular de la que debían surgir las autoridades locales tenía que ser efectiva. El espacio natural para la creación de una nueva ciudadanía política residía así en el Municipio. Este era, en la perspectiva de los gobernantes correntinos, además de la celúla básica del estado, el ámbito natural en el que debía asegurarse la extensión y el ejercicio de las libertades civiles y políticas. ${ }^{24}$

\section{El fracaso del gobierno de Pujol}

Pujol fracasó en sus intentos de desmilitarizar la provincia y, en consecuencia, sus proyectos de transformación de la estructura económica y política provincial fueron dejados de lado. En este fracaso la resistencia opuesta por los jefes departamentales y líderes milicianos del sur provincial cumplió un papel central. En realidad, nunca pudo el gobierno, asentado en la ciudad capital, extender en esta región su dominio. Probablemente, los testimonios más concluyentes de ese fracaso puedan advertirse en la incapacidad para limitar el poder que el ya mencionado caudillo de Curuzú Cuatiá, Nicanor Cáceres, ejercía en la región.

${ }^{23}$ Sobre el régimen de la tierra en Corrientes puede verse el ya citado texto de texto de Enrique Schaller, $L a$ distribución de la tierra ..., ob cit. 1995.

${ }^{24}$ Sobre el papel del municipio en los debates sobre la organización política rioplatense durante el período véase Marta Bonaudo y Elida Sonzogni, Los grupos dominantes entre la legitimidad y el control en Marta Bonaudo (dirección), Liberalismo, estado y orden burgués, Editorial Sudamericana, Buenos Aires, 1999, pp 27-96. 
Que las autoridades del estado local no contaban con capacidad efectiva para controlar los movimientos de Cáceres como los de otros líderes locales da testimonio el informe que un oficial dependiente de la administración provincial envió al gobernador durante una de las tantas oportunidades en que el caudillo se encontraba en prisión como castigo por haber organizado una revuelta contra el gobierno local. La carta ilustra, por un lado, sobre los mecanismos que regían la militarización en la zona. Por otro muestra el grado de independencia que había adquirido el líder de Curuzú, la forma ostensible en que se burlaba de la autoridad provincial y la impotencia de esta última para controlar sus movimientos. Cáceres se encontraba entonces prisionero en Goya, una ciudad en el sur provincial a orillas del Paraná, relataba este oficial de apellido García sin cumplir con las disposiciones de seguridad que le habian sido impuestas. Debía estar encarcelado e incomunicado. Sin embargo, se le permitía "...que entrase en el calavoso a dormir con él una mujer muy conosida por su conducta...”. Cáceres recibía permanentemente la visita de mujeres que le brindaban serenatas “...y en cada conclusión él decía, el Gral, que les suplicaba que no alsacen tanto la vos porque el estaba incomunicado y que no quería que nadie supiese y se reían todas a carcajadas...". Además de no hacerse efectiva la incomunicación, el oficial contaba al gobernador que Cáceres habia hecho traer una tropa de ganado de su estancia con la que habia sobornado a los oficiales obligados a custodiarlo.

El representante del gobierno acusaba al Jefe Político de Goya de permitir esta situación burlando así la confianza que en él había depositado el gobernador ${ }^{25}$. García terminaba por convencerse de la complicidad de las tropas supuestamente leales al gobierno y acantonadas en la ciudad a la hora de visitar el cuartel donde residían éstas. No había podido encontrar allí a la gran mayoría de los oficiales que, o estaban con licencia o se habían ido a cenar. Tampoco por razones similares había logrado que se cumpliese con éxito la orden de pasar lista a la tropa. Azorado, relataba al gobernador que el capitán le había respondido “...que no podía hacerlo porque havía muchos licenciados que no recordaban quienes heran....".Al no encontrar fuerzas leales al gobierno la ciudad estaba a merced de las tropas afectas a Cáceres. Alarmado, describía entonces el grado de desorganización de estas milicias y el saqueo sistemático que hacían de las casas y los bienes de los pobladores ${ }^{26}$.

${ }^{25}$ Durante la década de 1850 en algunos departamentos de la provincia el cargo de jefe político reemplazó al de comandante departamental.

${ }^{26}$ Comunicación de Juan García al Excmo Sr Gobernador Dn Juan Pujol, Goya, Octubre 31 de 1854:

Señalaba en relación a la prisión de Cáceres:

"En el mismo momento que llegue que serian como las doce de la noche ya me convensi que las disposiciones de V.E son infringidas y burladas completamente...," Agregaba posteriormente: "Tambien estoy informado que hizo traer Caceres, una tropa de ganado, la bendio y el dinero lo inbirtio en hacer dadivas a la tropa y a algunos oficiales, sobornandolos, de este modo a su favor, diciendoles que les tenia lastima porque beia las necesidades que estaban sufriendo..." Finalmente destacaba como "En el cuartel general suceden robos escandolosos diariamente que hasta las armas se llevan, en el pueblo noche por noche se escalan casas no dejan lecheras, terneros ni gallinas en las casa" En Archivo General de la Provincia de Corrrientes (AGPC), Correspondencia oficial, Tomo 146, Fojas 85-88. 
El informe de García mostraba además las dificultades para organizar fuerzas leales al gobierno en condiciones de hacer efectiva su autoridad en los departamentos de frontera de la provincia durante la década de 1850. Era extremadamente complicado obtener tanto los alimentos como los hombres necesarios para mantener a las fuerzas milicianas A menudo, cuando se trataba de agentes del gobierno asentados en la ciudad capital de provincia, las resistencias se hacían particularmente evidentes. En 1854, uno de los jefes de las milicias dependientes del gobierno provincial, de apellido Payba, testimoniaba las resistencias de los “...vesinos..." del departamento de Restauración a entregar las reses para alimentar a las tropas del estado. Señalaba asi que "...no habia vecino que pudiera auxiliarnos con la carne..." Uno de los "...hasendados..." de la zona se habia negado ante el pedido de un oficial "... diciendo que el habia comprado las haciendas que posee a patacones y que siendo para mi particular habia de enviarme de buena gana, mas si es para el Estado el no tiene animales para ausiliarnos"27. El oficial representante del gobierno escribía entonces con resignación ante el gobernador que los vecinos apoyaban sus argumentos en la Constitución y preocupado se preguntaba como iba a ser posible sostener una fuerza militar si aquellos “...por opinión...."no querían “...servir a la patria...”

Los testimonios de García y Payba, como otros señalados anteriormente, muestran, de todas formas, una voluntad permanente de los sectores ligados al gobierno local centrado en la ciudad capital por extender y afirmar el dominio del estado en todo el territorio provincial. Por otro lado, es preciso señalar que dicha intervención contemplaba diversos planos que afectaban las costumbres, los hábitos, las relaciones de clientela política y militar, los vínculos laborales de los miembros de esta sociedad entre sí, y, por supuesto el acceso a la tierra convertido en un elemento cada vez más significativo en la medida en que se extendía el predominio de la actividad ganadera. Sin embargo, a diferencia de lo sucedido en otros estados provinciales rioplatenses, la experiencia correntina mostraba con crudeza el carácter infructuoso de estos esfuerzos. Las derivaciones de este fracaso signarían por décadas, a nuestro entender, la historia de la provincia.

\section{La revolución de 1861, la construcción de un nuevo orden político en Corrientes, la inserción en el estado nacional en formación.}

Hacia finales de la década de 1850, el gobierno provincial se vio obligado a alentar un nuevo proceso de militarización local debido al recrudecimiento del conflicto entre la Confederación y Buenos Aires. Las autoridades de aquella veían entonces a la provincia de Corrientes y, particularmente a los departamento del sur provincial como el lugar de asentamiento de la retaguardia de sus ejércitos. Así, la dinámica del proceso suprarregional que se inició a finales de la década de 1850 acentuó la militarización de la provincia que Pujol había procurado detener y consecuentemente fortaleció a los jefes de Curuzú Cuatiá, Mercedes y Restauración entre otros departamentos ya que, como señalamos, eran localidades de frontera donde el peso de las milicias era particularmente relevante.

${ }^{27}$ De Eusebio Paiva al Excmo Señor Gobernador Juan Pujol, La Cruz, Octubre 6 de 1854, en $A G P C$, Correspondencia Oficial. Tomo 146, foja 21. 
Pero allí se encontraba con la oposición permanente de gran parte de la población y sobre todo de los comandantes departamentales que procuraban ejercer nuevamente y sin restricciones sus facultades militares. Estos jefes pretendían controlar y dirigir el proceso de militarización y reclutamiento, en forma personal y con independencia de las autoridades provinciales. En este sentido trataban de canalizar los vínculos con la población local para, entre otros propósitos, articular el mismo proceso de militarización con los ritmos de las actividades productivas en su zona. Su capacidad para mantenerse independientes del gobierno de la ciudad capital se reveló entonces con claridad. La rebelión contra el gobierno provincial, ejercida por un conjunto de jefes locales con mando sobre agrupaciones militares se manifestó al mismo tiempo, durante estos años, como parte de una lucha con el primero por regular y controlar el mismo proceso de militarización y de alguna manera también, paradójicamente, como una reacción contra un estado de guerra permanente.

Puede observarse entonces que, aunque la revolución efectivamente estalló en Noviembre de 1861, la resistencia al gobierno provincial en la zona se manifestó, como ya lo señalamos, de manera permanente en los años previos. El conflicto se expresó de formas diversas, pero, en general, siempre en estrecha vinculación con el reclutamiento y la organización miliciana y en disputa con aquél por la organización de dichos procesos. Ante las exigencias de convocatoria de fuerzas provenientes de la capital los jefes de las localidades aducían la falta de armamentos, vestuarios y de personas en condiciones de instruir adecuadamente a la tropa. Por otro lado, estos mismos jefes sostenían la imposibilidad de mantener un reclutamiento permanente. Recordaban así a las autoridades provinciales que recorrer las distancias entre el lugar de residencia y trabajo habitual y el de reclutamiento insumía varios días. Los “...vesinos..." se señalaba, se encontraban en pleno trabajo y debían recorrer entre 10 o 12 leguas para llegar al lugar donde se realizaba la instrucción. Por eso, sostenían, era inconveniente que se les exigiese concurrir a efectuar los ejercicios y prácticas en forma semanal. Las autoridades departamentales advertían entonces al gobierno que si éste insistía demasiado en presionar a través de la frecuencia e intensidad de las convocatorias “.....perdería su prestigio en la zona...."28

Pero, tal vez, la manifestación más clara de la oposición de la población, alentada muy probablemente, por las mismas autoridades de los departamentos se daba en el abasto de la tropa. Como han mostrado ya diversos trabajos, la posibilidad de consumir carne sistemáticamente constituía un aliciente para el reclutamiento en la milicia. Las tropas del ejército de línea como las de la guardia nacional se alimentaban fundamentalmente a base de carne. En consecuencia, el abasto de la guarnición era quizás el principal problema que debían afrontar los responsables de la organización miliciana. La correspondencia oficial del Gobierno de aquellos años muestra las dificultades permanentes del estado local para lograr con éxito dicho abastecimiento. Los funcionarios testimonian a tráves de sus informes las permanentes negativas de los grupos locales para proporcionar la carne o las reses. Las autoridades departamentales se limitaban a menudo simplemente a comunicar al gobierno

\footnotetext{
${ }^{28}$ El Jefe del Departamento al Excmo Señor Gobernador de la Provincia, Don José María Rolón, Curuzú Cuatiá, Noviembre 10 de 1861, en $A G P C$, Correspondencia oficial,Tomo 174, Foja 69.
} 
local dichas dificultades, aparentemente, sin presionar a la población de su jurisdicción al respecto. Los comandantes departamentales del sur actuaban así en su carácter de grandes propietarios, jefes milicianos y agentes del gobierno procesando estas tres funciones que, a menudo, obligaban a asumir medidas de carácter contradictorio. De esta forma, por un lado, eran responsables del reclutamiento de la tropa que se hacía a través de la misma comandancia. Por otro se hacían voceros de una reacción fuertemente antibélica que se daba en una región particularmente castigada por las guerras civiles. Es posible entonces afirmar que los jefes departamentales canalizaron, en gran medida, aquí las auténticas demandas contra la guerra y el reclutamiento originado en sus propias poblaciones

En este marco de tensión local se insertaba el conflicto entre la Confederación y Buenos Aires desatado a partir de septiembre de 1852. Los círculos gobernantes en esta última procuraron tempranamente socavar las posiciones federales y urquicistas en el interior y el litoral. En muchas de las provincias encontraron fuertes apoyos que, poco tiempo antes y, sobre todo después de Pavón actuaron con el respaldo de los ejércitos y del dinero porteño ${ }^{29}$. En este contexto, hacer efectiva la neutralización de Urquiza, exigía el control de Corrientes. Siendo por entonces uno de los miembros más radicalizados del círculo porteño, Domingo F. Sarmiento escribía al cordobés Justiniano Posse en Junio de 1856 que el punto débil de la Confederación urquicista era, precisamente, la provincia de Corrientes ${ }^{30}$. En un mismo tono, en octubre de 1861, en una comunicación dirigida a Bartolomé Mitre, entonces gobernador de la provincia, varios de sus colaboradores más cercanos habían aconsejado, como parte de una estrategia para neutralizar al líder entrerriano, apoyarse en los grupos afines de Corrientes y hacer imperar allí al partido libera ${ }^{31} \mathrm{Si}$ bien es entonces evidente que el gobierno provincial correntino, encabezado entonces por el sucesor de Juan Pujol, un antiguo colaborador de éste apellidado Rolón, cayó a raíz de un conflicto con fuertes raíces locales, el apoyo del gobierno de Buenos Aires fue decisivo y respondía a la ya mencionada estrategia de mediano plazo de los grupos porteños tendientes a desestabilizar a Urquiza y a asegurar su hegemonía y la de los sectores liberales a ellos afines en todo el espacio rioplatense ${ }^{32}$. La crisis del poder urquicista era, en este contexto, un factor que

${ }^{29}$ Un análisis de los sucesos que culminaron en Pavón narrados por un colaborador cercano a Urquiza puede verse en el ya mencionado texto de Julio Victorica, Urquiza y Mitre, ob cit 1986.

${ }^{30}$ Sarmiento a Posse, Buenos Aires, 15 de junio de 1856, Epistolario entre Sarmiento y Posse, Buenos Aires, Museo Histórico Sarmiento, pp 61-63.

${ }^{31}$ Manuel Ocampo, Pastor Obligado y Norberto de la Riestra se dirigían a Bartolomé Mitre señalando como estrategia ante una posible negativa de Urquiza a retirarse de la vida pública...”Más suponiendo esta hipótesis irrealizable, creemos que el mejor plan será buscar el resultado por la vía de Corrientes; es decir haciendo imperar allí el partido liberal mediante el apoyo material y directo de fuerzas de Buenos Aires" en Manuel Ocampo, Pastor Obligado y Norberto de la Riestra al Excmo Señor Brigadier General don Bartolomé Mitre, Buenos Aires, Octubre 13 de 1861 en Archivo del General Mitre, Tomo X, Buenos Aires, Biblioteca de la Nación, 1913, pp 15.

32 José María Rolón había reemplazado a Pujol en diciembre de 1859. Había nacido en Corrientes y se había formado en el Seminario Conciliar de Buenos Aires. Se había desempeñado como Vicario eclesiástico de la provincia de Corrientes y, durante el gobierno de Pujol, se había hecho cargo del sistema de instrucción primaria. Era, por otra parte, uno de los cuatro redactores de la Constitución provincial sancionada en octubre de 1855 . 
potenciaba la rebelión en el sur de la provincia y que, desencadenada poco después de Pavón, culminó en noviembre de 1861.

Mitre apoyó generosamente a los revolucionarios y, posteriormente, siguió asistiendo al nuevo gobierno de Corrientes. Esta dependencia financiera se institucionalizaría tiempo más tarde, como en otras provincias, a partir de los subsidios del estado nacional. La hegemonía mitrista en Corrientes operó entonces a partir del acuerdo que el líder porteño hizo con las fuerzas locales, sobre la base de tensiones y conflictos de larga data en la provincia. En este sentido es relevante el contraste que puede establecerse con otras provincias como Córdoba o algunas localidades del noroeste donde los federales afectos a Urquiza fueron neutralizados por fuerzas militares nacionales conducidas por jefes que respondían al gobernador de Buenos Aires. La presencia del ejército de línea liderado por los generales "orientales" no fue necesaria en Corrientes.

\section{Los revolucionarios}

Hacia finales de la década de 1850 surgió en la capital de la provincia una agrupación que nucleaba a varios de los miembros más selectos de su élite. Este grupo estaba liderado por Juan Eusebio Torrent y luego por José Pampín y Manuel Lagraña. En junio de 1860, estos últimos compraron una imprenta e instalaron un periódico, que fue el primero no oficial de la provincial y que recibó el nombre de La Libertad. Tiempo después quienes se expresaban a través del periódico fundaron el Club Libertad que nuclearía así al naciente liberalismo correntino. Los motivos que inspiraban a los liberales de la provincia se vinculaban con una militante oposición al gobierno provincial y al de la Confederación Argentina, a la vez que manifestaban su simpatía por los hombres que gobernaban Buenos Aires.

Los miembros del Club Libertad establecieron tempranamente vínculos aceitados con los líderes del sur provincial. En agosto de 1860, el períodico festejó la victoria de la lista opositora al gobierno provincial en departamentos como Curuzú Cuatiá y Restauración. En este último caso defendió abiertamente al juez de paz, Isidoro Fernández Reguera, acusado por el oficialismo de haber manipulado la elección. Varios de los líderes de aquellas regiones eran presentados aquí como verdaderos paladines de las libertades públicas frente al gobierno asentado en la ciudad capital acusado de despotismo y arbitrariedad. En octubre de 1860 se publicó en el periódico la adhesión al Club Libertad del propio Nicanor Cáceres ${ }^{33}$. El liberalismo correntino que había surgido entonces como un grupo esencialmente urbano y ligado a la capital provincial, había articulado lazos estrechos con los grupos dirigentes del sur, donde, por otra parte, algunos hombres de la ciudad ya tenían fuertes intereses vinculados a la propiedad de grandes extensiones de tierra. El discurso de los liberales contemplaba muchos de los reclamos que provenían de aquella región y que derivaban en

\footnotetext{
${ }^{33}$ Sostenía Cáceres: "Declaro a la faz de la Provincia de Corrientes y mi patria, q'tengo el honor de ser miembro del Club Libertad a cuyos principios e ideas me he adherido de todo corazón, porque comprendo que ellas tienden directamente al bien estar y engrandecimiento de este querido y desgraciado Pueblo", en Nicanor Cáceres al Sr. Director de La Libertad, Paraíso, Curuzú Cuatiá, Septiembre 20 de 1860, en La Libertad, 4 de Octubre de 1860.
} 
parte también de los efectos causados por la propia política del gobierno de la Confederación asentado en Paraná. Este último había afectado el desarrollo comercial de aquella región otorgando diverso tipo de privilegios a los puertos entrerrianos sobre los correntinos. De esta forma, el monopolio natural del comercio por parte del puerto entrerriano de Concordia derivado de factores geográficos que mencionamos anteriormente, era reforzado por la política comercial y aduanera de la Confederación. La situación fue denunciada por los primeros opositores y luego revolucionarios miembros del liberalismo correntino ${ }^{34}$.

Es cierto que los revolucionarios, en su conjunto, se autodenominaron liberales y proclamaron en forma entusiasta su adhesión a los sectores gobernantes en Buenos Aires. La retórica que impregnaba su discurso era claramente antientrerriana, antiurquicista y liberal. Se pronunciaban contra el caudillismo, contra Urquiza y su hegemonía sobre la provincia. Proclamaban fervientemente su adhesión a la figura de Mitre y a las políticas implementadas por el partido liberal hegemónico en Buenos Aires. Sin embargo, más allá de este rótulo y su harto proclamado antiurquicismo, las diferencias entre los dos grupos, por un lado el sector urbano asentado en la ciudad capital y por otro los jefes departamentales del sur provincial se fueron acentuando con el paso del tiempo.

Aunque estos últimos fueron los verdaderos organizadores y protagonistas de la revolución no ejercieron directamente el gobierno sino que lo delegaron en los hombres de la élite urbana, como los ya mencionados Pampín y Lagraña, líderes desde entonces del liberalismo correntino. Así se podría señalar que se trataba de un grupo bicéfalo, con un grado de heterogeneidad interna relativamente importante. En los dos casos, los principales exponentes del movimiento procuraron presentarse ante Mitre como las verdaderas cabezas del partido liberal de la provincia. Sin embargo mantuvieron diferencias entre ellos y, además, entre los propios jefes departamentales se originaron varias disputas que amenazaron la propia supervivencia del movimiento revolucionario.

La presión de los jefes departamentales sobre los hombres de la ciudad se manifestaba de manera continua. El hecho de que la política se manifestase en el sur, esencialmente a partir de la participación miliciana, era un factor que aquellos recordaban a los hombres de la élite urbana en la mayor parte de sus comunicaciones. En febrero de 1862, Raymundo Reguera, comandante del Departamento de Restauración felicitaba al gobernador electo José Pampín señalándole con respecto a su elección como gobernador “... así lo esperaba yo y la tropa que obedece mis órdenes..." 35 . A la vez, los hombres de la ciudad percibían con claridad que el poder residía en los jefes departamentales y en su organización miliciana. El mismo Luciano Torrent, uno de los principales líderes del grupo urbano, hacía

\footnotetext{
${ }^{34}$ Hemos abordado la cuestión del impacto de la política aduanera, comercial y de navegación implementada por el gobierno de la Confederación argentina en nuestro trabajo, Estado nacional y provincias bajo la Confederación argentina: una aproximación desde la historia de la provincia de Corrientes, en Desarrollo Económico, N 164, Buenos Aires, 2002, pp 643-664.

${ }^{35}$ Raymundo Reguera a José Pampín, Restauración, Campamento General en Laguna Abalos, 15 de febrero de 1862, en $A G P C$, Sala V, Fondo Mantilla, Archivo Pampín.
} 
referencia a la imposibilidad de llevar a cabo las elecciones por estar reunido entonces el ejército "...compuesto especialmente de los hombres de los Departamentos que habian de elegir...”. En este contexto hacía referencia a la necesidad de renovar la cámara. En ella, sostenía, eran mayoría los hombres que había derrocado la revolución y los departamentos que representaban les habían retirado "...algunos de los poderes..." 36

Mitre y algunos de los hombres de Buenos Aires más allegados a él habían mantenido vínculos estrechos con ambos grupos durante los meses que precedieron a la revolución. El papel que jugó el primero en la articulación y conducción general de este movimiento fue fundamental. Ofició como intermediario entre los líderes urbanos como Torrent y Pampín, por un lado y los comandantes departamentales como Reguera y Acuña, por otro. Además arbitró entre estos últimos en sus conflictos internos. Tanto los lideres del sector urbano, como los jefes de departamento se dirigían a él con frecuencia. Así, resulta clave la capacidad de Mitre para articular una red que comprendía a los principales actores de poder local. La conformación de esta red revela la habilidad de el entonces Presidente de la Nación para negociar y arbitrar en los conflictos entre los diferentes grupos de poder local. Esta capacidad podía ejercerse además en el contexto signado por la extrema debilidad de las instituciones políticas formales tanto locales como nacionales. El arbitraje de Mitre se verificaba no sólo con las nuevas autoridades de la provincia asentadas en la ciudad capital y con los jefes departamentales del sur, sino también con la figura del propio General Urquiza, gobernador todavia y "hombre fuerte" de la provincia de Entre Ríos. En este sentido, es preciso recordar que la extensión de la influencia mitrista en el litoral contó con el "visto bueno" del propio Urquiza.

Las relaciones entre estos cuatro actores, Mitre, Urquiza, la nueva élite política gobernante en la ciudad y los jefes militares de las regiones situadas del otro lado del río Corrientes son fundamentales para entender el funcionamiento de la política y las instituciones correntinas durante los primeros años de la decada de 1860. Los vínculos entre los mencionados en último término eran sumamente conflictivos. Los motivos que originaban las disputas eran diversos, pero amenazaron en más de una oportunidad con romper el equilibrio en el que se asentaba la nueva situación política provincial. Los jefes milicianos del sur imponían sus condiciones a los gobernantes asentados en la capital. Requerían la asignación formal de grados militares, dinero y armas para el sostenimiento de la tropa. Además sostuvieron con firmeza su decisión de controlar la sociedad local. En este sentido, siguieron exigiendo, por un lado, mantener la potestad para regular y controlar los procesos de reclutamiento y delimitar los ritmos de la militarización. Por otro lado, presionaban y sugerían permanentemente nombramientos y destituciones de funcionarios locales, particularmente de los jueces de paz, actores esenciales en el ordenamiento institucional de los departamentos. Los jueces de paz cumplían una función esencial en la regulación de los conflictos entre los diferentes protagonistas de la sociedad local. Su nombramiento estaba reservado al gobernador. En este sentido podían constituir una pieza

\footnotetext{
${ }^{36}$ Luciano Torrent a Bartolomé Mitre, Corrientes, 11 de enero de 1862, en Archivo del General Mitre, Tomo XII, Buenos Aires, Biblioteca de La Nación, 1912, pp 59-60.
} 
esencial para neutralizar el poder de los mismos comandantes departamentales. Incidiendo en su designación éstos completaban su control sobre la sociedad provincial. Mientras el manejo de las elecciones permitia controlar el nombramiento de los Diputados y de la Asamblea legislativa provincial, el de la Justicia de Paz aseguraba el dominio sobre la sociedad local. En este contexto, Raymundo Reguera, desde San Roque en marzo de 1862 comunicaba al gobernador Pampin la renuncia del Juez de Paz del Departamento de Bella Vista, Julio Camelino y proponía como reemplazante a Ruperto Montenegro “...bueno y seguro..." y que, afirmaba, no haría “...liga ninguna con las administraciones caducadas" ${ }^{37}$. Un mes mas tarde, su hermano, Isidoro Reguera escribía preocupado al gobernador porque este parecía no haber tomado en cuenta sus recomendaciones para el nombramiento de un nuevo Juez de Paz en el departamento de La Cruz. ${ }^{38}$. Estos jefes militares simultanéamente negociaban con Urquiza y amenazaban al gobierno provincial con la siempre postergada movilización de fuerzas entrerrianas en la frontera. Aunque públicamente la rebelión tuvo un claro tono antiurquicista muchos de sus protagonistas todavía mantenían con el "hombre fuerte" de la provincia de Entre Ríos vínculos muy aceitados de diferente carácter.

Los hombres de la élite urbana intentaron en más de una oportunidad deshacerse de los comandantes departamentales del sur. En enero y febrero de 1862, Pampín procuró licenciar a la tropa argumentando el cese del peligro de la invasión entrerriana. Aparentemente, el mismo Pampín buscó el apoyo de Mitre para neutralizar la influencia miliciana. Calificaba a estos grupos de antiliberales y señalaba al entonces encargado del Poder Ejecutivo Nacional, la necesidad de disciplinar y limitar su despotismo. Cuando en agosto de 1862 estalló una nueva y abierta revolución contra el gobierno provincial en Mercedes y Curuzú Cuatiá, Pampín le pidió a Mitre que mandara un escuadrón de línea a estacionarse en la zona. Por último, al enviarle una felicitación con motivo de su ascenso formal a la presidencia de la República en octubre de ese año volvía a señalarle los múltiples problemas que tenía con los hombres de la frontera.

Pero Mitre abogó siempre por el acuerdo y la conciliación entre estos grupos. Desalentó así todas las iniciativas del sector gobernante por enfrentarse con los jefes departamentales del sur. Tal vez porque entendía que en ellos residía el verdadero poder provincial o quizás incluso porque comprendía que era conveniente mantener el equilibrio entre las distintas facciones de los ahora grupos gobernantes de Corrientes. Así, le advertía a Pampín que debía buscar el apoyo en "... los hombres de acción" que habían protagonizado la revolución ${ }^{39}$. Más adelante le aseguraba que no debía temer por la posible nueva

\footnotetext{
${ }^{37}$ De Raymundo Reguera a Jose Pampín, San Roque, Marzo 14 de 1862, en AGPC, Sala V, Fondo Mantilla, Archivo Pampín, Tomo 17, sin foliar.

${ }^{38}$ De Isidoro Reguera a Jose Pampin, Restauracion, 13 de abril de 1862 en $A G P C$, Sala V, Fondo Mantilla, Archivo Pampín, Tomo 17, sin foliar.

${ }^{39}$ De Bartolomé Mitre a José Pampín, Buenos Aires, 9 de Agosto de 1862, AGPC, Fondo Mantilla, Archivo Pampín: “...V. debe comprender que la cuestión no está en resistir y triunfar, sino en impedir todo escándalo que pueda sobrevenir, pues en definitiva todo desorden mas o menos trascendental redundará en descrédito de la nueva situación impidiendo la consolidación de su gobierno y el predominio de la autoridad civil, nacida y apoyada en una revolución realizada por los hombres de acción.
} 
confabulación entre los hombres del sur provincial y Urquiza. En este sentido es preciso recordar que este último seguía siendo, de alguna forma, un personaje fundamental del nuevo marco político en el litoral rioplatense. El mismo control del proceso de militarización en la zona exigía negociar con él. Aunque la revolución de 1861 había implicado la liquidación definitiva de su influencia sobre la provincia, Mitre mostró su predisposición para negociar con Urquiza. Así, ante él y las élites correntinas, Mitre se erigió en garante de la estabilidad, la paz y el control del conflicto entre las dos provincias.

Por último Mitre demostró una notable capacidad de mediación entre los mismos jefes locales al evitar que las disputas internas, especialmente aquellas que tenían como protagonista a Nicanor Cáceres se profundizaran. Varios de los jefes departamentales trataron de expulsar a este último de la región. Lo identificaban, básicamente, con el poder urquicista. Pero este conservó ahora, en gran medida, gracias a Mitre, su influencia clave en la región. La relación que articuló el Presidente de la Nación con Cáceres constituye un tema a indagar. Sin duda, su intención de conservar en cierta medida el favor de Urquiza cumplió un papel central. Aparentemente en la articulación de este nuevo vínculo entre Caceres y Mitre fue fundamental también la intermediación de Pedro Ferré, un viejo dirigente local que actuó como emisario y representante del Presidente de la nación en la zona. Con la concesión de grados militares en el ejército nacional completó, el ya entonces Presidente constitucional su acuerdo con los jefes milicianos y comandantes departamentales del sur. Mitre, además, impuso el acuerdo con Cáceres al mismo gobernador provincial, José Pampín. ${ }^{40}$. En octubre de 1863, Caceres fue designado General de la Nación otorgándosele la Jefatura efectiva de las fuerzas del sur provincial. Puede observarse así que el liberalismo y las fuerzas afectas a Mitre conservaron en la provincia una tonalidad que las distinguía de sus símiles en otras localidades y que estaba signada por este apoyo de fuerzas que en otras provincias y regiones quedaron identificadas con los regímenes políticos derrocados en Caseros primero y luego en Pavón.

"En mis anteriores cartas he manifestado a V. Con franqueza mi modo de pensar sobre la actualidad de Corrientes y persisto en creer que con todos sus inconvenientes lo que conviene a V. Más hacer es apoyarse leal y decididamente en los hombres de acción que han creado la situación, impidiendo a la vez que ellos se dividan entre sí, pues de lo contrario considero que aun cuando pudiese Vsobreponerse materialmente a la acción de los Gefes de quien me ha transmitido V. Sus quejas anteriormente, esto no podría realizarse sino levantando otras más o menos odiosas, o más peligrosas, o más exigentes, dividiendo y debilitando el partido en que debe apoyarse su gobierno y creando inmensos peligros para el porvenir de la provincia en las condiciones politicas y topográficas en que se encuentra"

${ }^{40}$ Bartolomé Mitre a José Pampín, 17 de junio de 1862. Senalaba entonces Mitre a Pampin, luego de felicitarlo por la pacificacion de la provincia:

"Considero pues que, aceptando a Caceres en su retiro y procurando mas bien tenerlo por amigo, debe procurarse tranquilizar a este respecto al animo de aquellos jefes, haciendoles entender a la vez, que mas vale tener a Caceres de amigo que de enemigo, y que es mejor que el este dentro que fuera de Corrientes, desde que esos jefes deben tener completa confianza en la lealtad de caracter de V.E y en los intereses del pais que le aconsejan apoyarse en la revolucion que ha producido su actualidad". En AGPC, Sala V, Fondo Mantilla, Archivo Pampin, Tomo N 17. Sin foliar 


\section{Reflexiones finales}

La revolución de 1861 marcó claramente la crisis del proyecto que pretendía moldear, organizar y controlar el espacio provincial desde la ciudad. Signó el fin del poder de una élite política urbana relativamente independiente que procuraba llevar a cabo un proyecto de desarrollo institucional para Corrientes asentado, entre otros aspectos, en una fiscalidad regular sobre la base de la contribución directa y un sistema de administración de la tierra pública que condujese a una privatización controlada y moderada que, además, posibilitase el asentamiento de inmigrantes en parcelas medianas o pequeñas. Este proyecto procuraba también asegurar el poder del gobierno provincial a través de la organización municipal y la instalación en ellas de funcionarios relativamente independientes de las preexistentes redes de influencia local. La derrota del grupo político que impulsó estas iniciativas reveló con enorme claridad la hegemonía e independencia que había adquirido la región del sur provincial como tambien su crecimiento en términos económicos, políticos y estrátegicos. Años más tarde, en 1867, el redactor de uno de los periódicos principales de la provincia, El Eco de Corrientes, recordaría aquellos años por la hegemonía ejercida por las fuerzas del sur provincial sobre el gobierno local, señalando que esto había constituido un fenómeno inédito en la historia de la provincia. ${ }^{41}$. Este movimiento revolucionario alteró además, definitivamente la naturaleza del poder político local que hasta entrada la década de 1830 había sido ejercido por una élite de comerciantes artesanos y letrados cuyos orígenes se remontaban a las últimas décadas de la colonia. De ahora en más, estos sectores deberían compartir el poder con un grupo de jefes departamentales fuertemente militarizados que controlaban extensas zonas del territorio provincial cuya fisonomía estaba basada casi exclusivamente en la ganadería.

Un año después, a finales de 1862, las verdaderas consecuencias de la revolución sobre la estructura institucional y política de la provincia eran evidentes. También lo era en quienes había pasado a residir el poder real y efectivo en la provincia. Quizás ningún testimonio lo expresa con mayor claridad que la comunicación elevada por un notable local, Juan Camelino al ex gobernador José Pampín, en enero de 1863. Camelino había sido juez de paz del departamento de Bella Vista y había renunciado a ese puesto poco tiempo después de la revolución de noviembre. Ante Pampín se proclamaba liberal pero cuestionaba con firmeza la alianza de los hombres de su agrupación con aquellos que entendía constituían una verdadera “... amenaza...." Así, Camelino hacía evidente el conflicto entre los hombres de gobierno calificados de "...caudillos de pluma, de anarquistas, de ambiciosos...." por aquellos mismos que habían arrebatado al pueblo la que entendía era su derecho y prerrogativa más importante "... la libertad de sufragio". Hacía notar entonces la imposibilidad de generar un sistema de organización y participación y ejercicio de los derechos políticos sobre la base del dominio y la hegemonía miliciana tal como se la conocía en Corrientes. Denunciaba además con vigor el despotismo de los jefes departamentales y el predominio de las agrupaciones armadas en la vida política correntina. Si bien muchos trabajos recientes han

${ }^{41}$ En El Eco de Corrientes, 15-10-1867. 
destacado la relación entre las formas de participación política y el servicio en la milicia, el testimonio de Camelino hacía entreveer a ambas formas como incompatibles ${ }^{42}$. La revolución liberal en Corrientes se manifestaba como el ascenso del despotismo y testimoniaba el fracaso de los proyectos por disciplinar a la élite local desde el estado provincial. A este fracaso, por supuesto, no era ajena la estrategia llevada a cabo por Mitre para desestructurar al estado confederal, subordinar a Urquiza y asegurar su hegemonía sobre el conjunto del espacio rioplatense.

La revolución de noviembre de 1861 tuvo consecuencias importantes para el futuro provincial. La descentralización del poder político local constituyó desde entonces un dato básico de la evolución de la provincia. Esta descentralización involucró no sólo a la organización miliciana sino también al sistema de percepción de impuestos que como, analizamos, quedó en manos de comisiones controladas por la élite de cada uno de los departamentos. En gran medida esto explica, a nuestro entender, dos fenómenos característicos de la historia provincial en la segunda mitad del siglo: por un lado el déficit crónico de su estado y, por otro, su inestabilidad política que se tradujo en permanentes rebeliones contra el gobierno asentado en la capital provincial. Estos fenómenos acentuaron, a la vez, la intervención del estado nacional en la provincia y la crisis de la autonomía local. La imposibilidad de construir un sistema viable de ingresos fiscales generó la dependencia del subsidio nacional, como se verificó en otras provincias rioplatenses. La inestabilidad política hizo que el gobierno nacional decretara en varias oportunidades la intervención federal ante la imposibilidad de la provincia de regular en forma más o menos armónica sus conflictos internos. A diferencia de otras provincias del litoral argentino, Corrientes no sólo no logró incrementar su población a través del asentamiento de colonias de inmigrantes sino que, además, asistió a la emigración de gran parte de su población nativa. Como se expresara en un informe presentado a una exposición nacional celebrada en Córdoba en 1869 las causas de ese fenómeno residían en la movilización permanente de la guardia nacional y en el imperfecto sistema adoptado con respecto a la distribución de la tierra pública. ${ }^{43}$

${ }^{42}$ De Julio Camelino a José Pampín, Bella Vista, Enero 29 de 1863, en $A G P C$, Fondo Mantilla, Archivo Pampín. Le señalaba entonces Camelino a Pampín refiriéndose a la nueva situación política creada en la provincia. "Por otra parte, mi amigo, al pueblo no se lo educa, ni se le hace conocer sus derechos con hacer centenares de jefes y oficiales, que siempre serán la rémora más grande para llevar a cabo esa obra; (...). A esos Gefes, á esos oficiales de nuevo cuño, es á los que se les debe hacer comprender primero que ellos deben ser los verdaderos guardianes y sostenedores de los derechos del pueblo, y no los destructores de ellos ni los opresores de aquel"

Más adelante agregaba:

"Crea, mi amigo; los que de buena fe quieran asociarse para educar al pueblo y hacerle comprender que nadie puede arrebatarle sus libertades, tiene que tropezar a cada paso con la punta de tanta espada que inutilmente han levantado, sin pensar que ese elemento en su mayor parte no ha de querer desprenderse de la preponderancia que adquirió en la pasada administración"

${ }^{43}$ Vease Cecilio Echevarría y Ramón Contreras, Informe acerca de la Provincia de Corrientes presentado a la Comisión Directiva de la Exposición Nacional de Córdoba, Buenos Aires, Imprenta, Litografía y Fundición de tipos a vapor de la Sociedad Anónima, Buenos Aires, 1873. 
La historia correntina muestra así el fracaso de los intentos de modelar la estructura económica y social de la provincia desde el antiguo aparato de estado derivado de los tiempos coloniales. A diferencia de otros centros urbanos de la Argentina, la capital correntina no pudo afirmarse en su papel de estructurador y organizador del conjunto del espacio provincial. La inestabilidad que caracterizó a su vida política debe entenderse en este marco, el signado por la ausencia de un núcleo de poder interno con capacidad de arbitrar y resolver los conflictos locales. ${ }^{44} \mathrm{El}$ mitrismo, hegemónico a nivel nacional, fue, por otra parte, a través de su plan de alianzas locales, funcional a una estrategia que tuvo como resultado la desarticulación del poder político local. La imposibilidad de fortalecer el orden interno impidió, finalmente, a la élite correntina, como recordara a menudo el célebre historiador Hernán Gómez, incidir en las decisiones nacionales.

\section{Cuadro anexo}

\section{Densidad de población de los departamentos por kilómetro cuadrado}

$\begin{array}{ll}\text { Ciudad } & 169,79 \\ \text { Lomas } & 2,60 \\ \text { Empedrado } & 1,20 \\ \text { Bella Vista } & 1,73 \\ \text { Lavalle } & 2,29 \\ \text { Goya } & 1,72 \\ \text { Esquina } & 0,85 \\ \text { Curuzú Cuatiá } & 0,78 \\ \text { Monte-Caseros } & 0,83 \\ \text { Paso de los Libres } & 1,25 \\ \text { La Cruz } & 0,40 \\ \text { Santo Tomé } & 0,21 \\ \text { Iratí } & 1,01 \\ \text { San Cosme } & 2,91 \\ \text { San Luis } & 1,24 \\ \text { Caá-Catí } & 1,76 \\ \text { San Miguel } & 0,48 \\ \text { Yaguareté Corá } & 1,01 \\ \text { Mburucuyá } & 2,90 \\ \text { Saladas } & 1,90 \\ \text { Mercedes } & 0,91 \\ \text { San Roque } & 1,71 .\end{array}$

Fuente: Primer Censo de la República Argentina, ob. cit, pp 214.

\footnotetext{
${ }^{44}$ Análisis de casos provinciales en los que puede observarse la capacidad del centro urbano y del estado local en él apoyado para organizar y dominar el conjunto de su espacio territorial en Tulio Halperín Donghi, "Clase terrateniente y poder político en Buenos Aires", en Cuadernos de Historia Regional, N 15, Buenos Aires, 1992, pp 11-45 y Rodolfo Richard Jorba, "La construcción y consolidación del poder oligárquico en Mendoza. 1789-1880. Crisis económica, reorientación productiva y hegemonía política" en Avances del Cesor No 3, Rosario, 2001, pp 57-88.
} 


\title{
Resumen
}

Este estudio describe las políticas de militarización en la provincia de Corrientes durante las décadas de 1840,1850 y 1860 . El texto procura analizar el impacto de estas políticas sobre la Revolución provincial de 1861. El autor subraya la importancia de de esta revolución en la caída del estado de la confederación argentina en 1861.

$<$ Militarización $><$ caudillo $><$ provincia $><$ confederacion $>$

\begin{abstract}
This study describes the military policies in province of Corrientes during the 1840,1850 and 1860 decades. This paper attemps to analyse the impact of these policies on the provincial revolution of 1861. The author underlines the importance of these events in the fall of Confederation Argentine State in 1861.
\end{abstract}

$<$ Army $><$ caudillo $><$ province $><$ Confederation $>$ 